\title{
The Relationship between Oncology Nurses' Practice behaviors, Knowledge and Confidence regarding Chemotherapy Induced Peripheral Neuropathy
}

${ }^{1}$ Ass.prof. Shereen Ahmed Qalawa, ${ }^{2}$ Dr.Dena Eltabey Sobeh, ${ }^{3}$ Dr.Fatma Elemam Hafez

${ }^{1}$ Assistant Professor of Medical-Surgical Nursing, Faculty of Nursing, Port-said University, Egypt; ${ }^{2}$ Lecturer of Medical-Surgical Nursing, Faculty of Nursing, Port-said University, Egypt;

${ }^{3}$ Lecturer of Community and family health Nursing, Faculty of Nursing, Port-said University, Egypt

\begin{abstract}
Background: Chemotherapy induced peripheral neuropathy [CIPN] is a significant debilitating side effect resulting from the administration of neurotoxic chemotherapy agents. Aim: The present study aimed to determine the relationship between oncology nurses' practice behaviors, knowledge and confidence regarding chemotherapy induced peripheral neuropathy. Subject and methods: A descriptive exploratory research study was carried out. Study sample: all available nurses(50) from the outpatient clinics of the oncology hospital in El-Mansoura University who were included in this study during four months from the starting of data collection using one tool; A structured interview questionnaire to assess nurses' practice behaviors, knowledge and confidence regarding Chemotherapy Induced Peripheral Neuropathy which includes four main parts: demographic characteristics, oncology nurses' practice behaviors sheet, oncology nurses' assessment knowledge sheet and oncology nurses' self-confidence. Results: the result of the present study revealed that, $62 \%$ of the studied nurses had unsatisfactory score of knowledge, all of nurses had satisfactory score of practice, and $66 \%$ of the studied nurses had high confidence score regarding chemotherapy Induced Peripheral Neuropathy. Conclusion: The results concluded that there were no statistically significant relations between oncology nurses' Knowledge with practice behaviors and confidence, there were positive correlation between nurses' knowledge and practice and there were negative correlation between knowledge and confidence but it did not reach a significant level.. Recommendations: Hospital directors should offer educational practical workshops for oncology nurses regarding neurological tests especially for chemotherapy induced peripheral neuropathy and give nurses' confidence to applying neurological tests and follow -up regarding assess chemotherapeutic patients for peripheral neuropathy.
\end{abstract}

Key Words: Chemotherapy Induced Peripheral Neuropathy, Oncology nurses, confidence 


\section{INTRODUCTION}

Commonly used chemotherapeutic agents in oncology/hematology practice, causing toxic peripheral neuropathy, include taxanes, platinum compounds, vinca alkaloids, proteasome inhibitors, and antiangiogenic/immunomodulatory agents (Argyriou et al, 2014). Thus , Chemotherapy induced peripheral neuropathy [CIPN] is a significant debilitating side effect resulting from the administration of neurotoxic chemotherapy agents. It is estimated that a third of all patients undergoing chemotherapy experience CIPN, with a third of those progressing to a permanent neuropathy. Patients experiencing moderate to severe CIPN report reduced quality of life, chronic discomfort and disruption of physical abilities for general life activities which can be temporary or permanent. Moreover, CIPN can lead to a dose reduction or possible cessation of treatment, which may adversely impact disease outcomes (Schloss, 2016).

Chemotherapy-Induced Peripheral Neurotoxicity (CIPN) is a frequent, potentially severe and dose-limiting side-effect of cancer treatment. Despite its clinical relevance that limits the use of several antineoplastic agents and even the future development of new anticancer drugs, several crucial aspects of CIPN remain unsolved, one of which is how to assess its occurrence and severity in the most effective and reliable way (Cavaletti et al, 2009). The incidence of chemotherapy-induced peripheral neuropathy (CIPN) is increasing because more neurotoxic drugs have been developed and because patients are living longer and receiving multiple chemotherapy regimens (Wickham , 2007)

CIPN can be painful and/or disabling, causing significant loss of functional abilities and decreasing quality of life. This can lead to dose reductions, discontinuation of treatment and may thus, ultimately, affect survival. Risk factors for CIPN include dose per cycle, cumulative dose, treatment schedule, duration of infusion, administration of other chemotherapeutics, comorbidity and pre-existing peripheral neuropathy. The exploration of polymorphisms in genes associated with incidence or severity of neuropathy might result in identifying individuals being at higher risk of neurotoxicity (Miltenburgand Boogerd, 2014)

Thus, the successful treatment of patients with CIPN includes managing pain, preventing progression of this side effect and assuring patient safety while treating the cancer with optimal chemotherapeutic doses. Among the many challenges that a patient with cancer faces, perhaps one

of the most poorly understood, yet most life-changing, is CIPN. It can greatly affect the quality of life for patients already facing many other difficulties arising from a cancer diagnosis. The pain and dysfunction associated with CIPN can impact a patient's life in many ways, from "simple" things such as buttoning a shirt or opening a jar, to pain that affects nearly every daily activity and interferes with sleep. It is essential for nurses to know the presenting symptoms, risk factors associated with and evidence-based management of CIPN (Maloney, 2012) 
Furthermore, Nurses are in an ideal position to support and advise patients and their families on issues related to treatment decisions. They are important resources for patients who have questions and concerns related to therapy, including about the range of available treatment options (e.g., supportive care alone), the goals of therapy, their prognosis, associated toxicities, and the impact of treatment on quality of life. Nurses should act to ensure, through appropriate teaching and coaching, that patients have a necessary understanding of their treatment options, thereby enabling them to make informed treatment decisions that are congruent with their own values and goals for life and living. Additionally, nurses play a key role in the follow-up and rehabilitation of patients following adjuvant treatment. Rehabilitation may occur within medical or surgical oncology practice or in a primary care setting. In addition to providing medical surveillance, nurses are well equipped to provide follow-up on many of the toxicity-related consequences affecting patients who have received adjuvant chemotherapy (Martelli-Reid et al, 2007)

Despite current work practice guidelines, nurses exposed to hazardous drugs still experience serious side effects that are influenced by: drug handling circumstances (preparation, administration, or disposal), amount of drug prepared, frequency and duration of drug handling, potential for absorption, use of ventilated cabinets, personal protective equipment (PPE) and work practices Krstev et al,2003)

Compliance with guidelines for handling Control Diseases (CDs) has been reported to be sporadic. In addition, measurable concentrations of some hazardous drugs have been documented in the urine of health care workers who prepared or administered them, even after safety precautions had been employed. Occpational Safety Health OSH (2010) Environmental studies of patient-care facilities have documented measurable concentrations of drug contamination, even in settings thought to be following recommended handling guidelines. Although there has been an increased awareness and concern regarding the issue of safe handling of $\mathrm{CDs}$, many nurses may still not follow the guidelines and procedures in the hospital settings and may not use the recommended safety equipment. In our hospital nurses are especially exposed while preparing and administrating CDs. For that reason the need to provide nurses with information about possible toxicities and required protection measures is very high (Cavaletti et al, 2009).

\section{Significance of study:}

There is a lack of research regarding real-time assessment of CIPN using well-known clinical instruments by either bedside nurses or advanced practitioners. Additional research is necessary using neurologic physical assessment data in studies of CIPN, although there has been an increased awareness and concern regarding the issue of safe handling of CDs, many nurses may still not follow the guidelines and procedures in the hospital settings and may not use the recommended safety equipment. In our hospital nurses are especially exposed while preparing and administrating CDs. For that reason the need to provide nurses with information about possible toxicities and required protection measures is very high. . So this study carried out tdetermine the relationship between oncology nurses' practice behaviors, knowledge and Confidence regarding Chemotherapy Induced Peripheral Neuropathy 


\section{AIM OF THE STUDY:}

The present study aimed to determine the relationship between oncology nurses' practice behaviors, knowledge and Confidence regarding Chemotherapy Induced Peripheral Neuropathy through:

1- Assess oncology nurses' knowledge regarding Chemotherapy Induced Peripheral Neuropathy

2- Assess oncology nurses' practice behaviors regarding Chemotherapy Induced Peripheral Neuropathy

3- Assess oncology nurses' self-confidence regarding Chemotherapy Induced Peripheral Neuropathy

4- Find out the correlation between oncology nurses' practice behaviors, knowledge and Confidence regarding Chemotherapy Induced Peripheral Neuropathy

\section{Research Questions:}

1- What is the oncology nurses' knowledge regarding Chemotherapy Induced Peripheral Neuropathy?

2- What is the oncology nurses' practice behaviors regarding Chemotherapy Induced Peripheral Neuropathy?

3- What is the oncology nurses' self-confidence regarding Chemotherapy Induced Peripheral Neuropathy?

4- Is there a correlation between oncology nurses' practice behaviors, knowledge and Confidence regarding Chemotherapy Induced Peripheral Neuropathy?

\section{Conceptual definitions:}

Chemotherapy Induced Peripheral Neuropathy: Chemotherapy induced peripheral neuropathy (CIPN) is a potentially dose limiting side effect of commonly used chemotherapeutic agents. Supposed pathogenetic mechanisms of CIPN are axonopathy through dying back axon damage and neuronopathy in which the cell bodies of the dorsal root ganglia are involved.

Self-confidence: it is defined as the ability of an individual; nurse to perform psychomotor skills which psychomotor skills are skills that require both mental and motor ability (Jeffries, 2007). 


\section{SUBJECT AND METHODS:}

A Descriptive exploratory research design was used to conduct this study

\section{The study sample:}

All available nurses (50) from the outpatient clinics of oncology hospital in El-Mansoura university hospital were included in this study.

\section{Tool of data collection:}

\section{Tool I: A structured interview sheet:}

It was developed by Binner (2010) to assess oncology nurses' knowledge, practice behaviors, and confidence regarding Chemotherapy Induced Peripheral Neuropathy and translated to simple Arabic language. This tool included 4 main parts as follows:

\section{Part I:}

It included demographic characteristics, such as age, level of education, years of experience worked in nursing and oncology field, oncology patients' care training courses and Chemotherapy training courses.

\section{Part II: Oncology nurses' assessment knowledge sheet:}

It includes 16 questions as 6 multiple choice questions and 10 true and false questions to assess nurses' knowledge regarding chemotherapy induced peripheral neuropathy such as orthostatic hypotension may indicate autonomic CIPN, chemotherapeutic agents causing CIPN may affect position and vibration sense, impaired proprioception may be a symptom of CIPN, the peripheral nervous system includes autonomic nerves, sensory symptoms of CIPN typically progress in a proximal to distal pattern, the stocking-glove distribution of sensory symptoms of CIPN refers to the paresthesias in the hands and feet. Each statement multiple choice questions follows with 4 optional choices and questions for true and false questions follows by two selective choice yes or no which correct answer for all question types take score 1 and false answer take score zero.

Then scored and calculated finally as satisfactory nurses' knowledge level scores $\geq 60 \%$ and unsatisfactory knowledge level scores $<60 \%$ based on (McAllister, 2010)

\section{Part III: Oncology nurses' practice behaviors sheet}

It includes 16 multiple choices questions to assess nurses' practice behaviors regarding assessment of baseline presence of peripheral neuropathy prior to initiating the first dose of chemotherapy, patient's ability to perform fine motor skills (e.g., button clothes, use of zippers), documentation CIPN assessment data, assessment of deep tendon reflexes on patients receiving neurotoxic chemotherapy, assessment of muscle strength on patients receiving neurotoxic chemotherapy, assessment of patients for the presence of other risk 
factors associated with peripheral neuropathy, objective motor function assessment skills (e.g., muscle strength, gait assessment), nursing assessment of CIPN prior to each infusion of neurotoxic chemotherapy, symptoms related to chemotherapy-induced peripheral neuropathy, patients strategies for adapting to functional impairments secondary to CIPN, and patients' education about safety precautions used to avoid injuries associated with CIPN (e.g., thermal injury, falls).

The likert scale choices ranged from (0-4) as follow never, occasionally, frequently and always respectively and the total score is considered satisfactory if the total nurses' practice is $(\geq 75 \%)$ and is considered unsatisfactory if the total nurses' practice is $(<75 \%)$ based on (Elgharib et al ,2012) .

\section{Part IV: Oncology nurses' self-confidence:}

The self-rated confidence questions are rated to indicate level of confidence in performing neurological physical assessment skills on a scale of 0-3 (Not at all confident, somewhat confident, confident, and very confident). The likert scale used to assess deep tendon reflexes, tuning fork vibration sensation, sharp vs. dull sensation, Romberg test, and manual muscle strength testing. These are not summed however, are reported as percentages as high self confidence level $(\geq 50 \%)$ and low confidence level $(<50 \%)$ based on (Smith et al ,2008 \& Binner,2010 )

\section{Methods of data collection:}

This study was covered in four phases:-

1-validity of tool:-. 5 experts were reviewing the content validity of the tool from oncology medicine and medical surgical nursing professor in the field after translation of the tool from English to Arabic language.

\section{2- Reliability:}

Was carried out through using Cronbach alpha test ( 0.084)

\section{3- Ethical considerations:}

Approval was taken from oncology hospital director and head nurses before starting the research and data were collected after explaining the aim of the study to all nurses who participated in the study.

4- Pilot study: - Pilot study was carried out after the development of the tools on $10 \%$ of the nurses to test applicability of the tools then necessary modification were done according to the results of pilot study and expertise opinions. The purpose of pilot study was:

1 - To test the applicability and feasibility of the study tools. 
2- To estimate any need for addition or omission in the tool, and time needed to fill in the tool.

Otherwise, these nurses were then excluded from the sample of research work to assure the stability of answers

5- Field work: data were collected from outpatient clinic of oncology hospital at Elmansoura university hospital in Elmansoura City at four months from September 2016 until December 2016 for three days weekly mainly Saturday ,Sunday and Thursday in the morning shift, each week according to time available to nurses . Each nurse takes time approximately between 30-45 minutes to fill a questionnaire.

\section{Statistical analysis:}

Data was collected and entered into a database file. Statistical analysis was performed using the SPSS 19 computer software statistical package. Data was described by summary tables and figures, Chi-2 was used to test the association between two qualitative variables and test, Monte Carlo for Chi square test, Fisher Exact for Chi square test were used to compare between two or more proportion. Statistical significance was considered at P-value $<0.05$

\section{RESULTS:}

Table (1): illustrates that, $60 \%$ of nurses were at age group $30-42$ years, $80.0 \%$ of them were females and married, $42 \%$ of them were bachelor level of education, $60 \%$ of them were nursing specialist, $54.0 \%$ of them had 5-10 years of experience, $52.0 \%$ of them had 5-10 years of experience in oncology, all of nurses received oncology patients' care training courses and $98 \%$ of nurses received chemotherapy training courses.

Table (2): indicated that, all of nurses had incorrect answers related to nonpharmacologic strategies and part of the assessment of patients suspected of having CIPN and the majority of them had incorrect answers related to chemotherapy agents commonly associated with CIPN and the essential first step in assessing CIPN. All of nurses had correct answers related to oncology patients with diabetes or alcoholism are at greater risk for developing CIPN and assessment of neuropathic pain requires a separate and unique approach compared assessment of nociceptive (tissue) pain and the majority of them had correct answers related orthostatic hypotension may indicate autonomic CIPN, impaired proprioception may be a symptom of CIPN and sensory symptoms of CIPN typically progress in a proximal to distal pattern.

Table (3): illustrates that, $62 \%$ of the studied nurses had unsatisfactory knowledge score of knowledge regarding chemotherapy Induced Peripheral Neuropathy with (Mean \pm $\mathrm{SD}, 9.36 \pm 0.98)$

Table (4): shows that, all of nurses gave always response to screen for baseline peripheral neuropathy, assess deep tendon reflexes, assess muscle strength, assess for other risk factors associated with peripheral neuropathy, assess motor function skills 
(e.g., gait), teach patient strategies for adapting to CIPN functional impairment and teach safety precautions used to prevent injuries associated with CIPN (e.g., falls). For total practice score, all of nurses had satisfactory practical behaviors regarding chemotherapy Induced Peripheral Neuropathy with (Mean \pm SD,38.20 \pm 0.67)

Table (5): illustrates that, $96.0 \%$ of nurses gave very confidence response to Romberg test, $66.0 \%$ of them gave confidence response to tuning fork vibration sensation, $48.0 \%$ of them gave somewhat response to deep tendon reflexes and $42.0 \%$ gave Not at all response to deep tendon reflexes. For score of confidence, $66 \%$ of the studied nurses had high confidence score regarding chemotherapy Induced Peripheral Neuropathy with (Mean \pm SD, $13.33 \pm 86.67$ )

Table (6): clarifies that, there were no statistically significant relations between oncology nurses' Knowledge with practice behaviors and confidence.

Table (7): illustrates that, there were positive correlation between nurses' knowledge and practice, negative correlation between knowledge and confidence but it did not reach a significant level, and a statistically significant negative correlation between practice and confidence. Also there were statistically significant relation between knowledge and practice. 
Table (1): frequency distribution of the studied nurses according to socio-demographic data $(n=50)$

\begin{tabular}{|c|c|c|}
\hline & No. & $\%$ \\
\hline Age & & \\
\hline $18-30$ & 20 & 40.0 \\
\hline $30-42$ & 30 & 60.0 \\
\hline Sex & & \\
\hline Male & 10 & 20.0 \\
\hline Female & 40 & 80.0 \\
\hline Marital status & & \\
\hline Single & 7 & 14.0 \\
\hline Married & 40 & 80.0 \\
\hline Divorced & 2 & 4.0 \\
\hline Window & 1 & 2.0 \\
\hline Level of education & & \\
\hline Diploma & 10 & 20.0 \\
\hline Technician & 19 & 38.0 \\
\hline Bachelor & 21 & 42.0 \\
\hline Current job & & \\
\hline Nurse & 20 & 40.0 \\
\hline Nursing specialist & 30 & 60.0 \\
\hline Years of experience in nursing & & \\
\hline$<5$ & 1 & 2.0 \\
\hline $5-10$ & 27 & 54.0 \\
\hline$>10$ & 22 & 44.0 \\
\hline Min. - Max. & \multicolumn{2}{|c|}{$4.0-17.0$} \\
\hline Mean \pm SD & \multicolumn{2}{|c|}{$10.26 \pm 3.31$} \\
\hline Years of experience in oncology & & \\
\hline$<5$ & 1 & 2.0 \\
\hline $5-10$ & 26 & 52.0 \\
\hline$>10$ & 23 & 46.0 \\
\hline Min. - Max. & \multirow{2}{*}{\multicolumn{2}{|c|}{$\begin{array}{c}4.0-17.0 \\
1046+341\end{array}$}} \\
\hline Mean \pm SD & & \\
\hline \multicolumn{3}{|l|}{ oncology patients' care training courses } \\
\hline Yes & 50 & 100.0 \\
\hline No & 0 & 0.0 \\
\hline \multicolumn{3}{|l|}{ Chemotherapy training courses } \\
\hline Yes & 49 & 98.0 \\
\hline No & 1 & 2.0 \\
\hline
\end{tabular}


Table (2): Oncology nurses' knowledge regarding Chemotherapy Induced Peripheral Neuropathy $(\mathrm{n}=50)$

\begin{tabular}{|l|c|c|c|c|}
\hline & \multicolumn{2}{|c|}{ Incorrect } & \multicolumn{2}{c|}{ Correct } \\
\cline { 2 - 5 } & No. & \% & No. & \% \\
\hline $\begin{array}{l}\text { Non-pharmacologic strategies to management of symptoms } \\
\text { associated of CIPN }\end{array}$ & 50 & 100.0 & 0 & 0.0 \\
\hline Chemotherapy agents commonly associated with CIPN & 45 & 90.0 & 5 & 10.0 \\
\hline An unpleasant, abnormal sensation & 20 & 40.0 & 30 & 60.0 \\
\hline Part of assessment suspected of having CIPN & 50 & 100.0 & 0 & 0.0 \\
\hline A critical element in the clinical assessment CIPN & 35 & 70.0 & 15 & 30.0 \\
\hline The essential first step in assessing CIPN & 46 & 92.0 & 4 & 8.0 \\
\hline Orthostatic hypotension may indicate autonomic CIPN. & 5 & 10.0 & 45 & 90.0 \\
\hline Impaired proprioception. & 1 & 2.0 & 49 & 98.0 \\
\hline The peripheral nervous system autonomic nerves. & 13 & 26.0 & 37 & 74.0 \\
\hline Sensory symptoms of CIPN & 2 & 4.0 & 48 & 96.0 \\
\hline The stocking-glove distribution of sensory symptoms of CIPN & 24 & 48.0 & 26 & 52.0 \\
\hline Toxicity scales used to grade CIPN are very precise. & 9 & 18.0 & 41 & 82.0 \\
\hline Symptoms of peripheral neuropathy. & 32 & 64.0 & 18 & 36.0 \\
\hline Oncology patients at greater risk for developing CIPN. & 0 & 0.0 & 50 & 100.0 \\
\hline Assessment of neuropathic pain. & 0 & 0.0 & 50 & 100.0 \\
\hline
\end{tabular}

Table (3): Oncology nurses' total knowledge score regarding chemotherapy induced peripheral neuropathy $(\mathrm{n}=50)$

\begin{tabular}{|c|c|c|}
\hline & No. & $\%$ \\
\hline Knowledge & & \\
\hline$<60$ unsatisfactory & 31 & 62.0 \\
\hline$\geq 60$ satisfactory & 19 & 38.0 \\
\hline Total score & \multirow{2}{*}{\multicolumn{2}{|c|}{$1.0-16.0$}} \\
\hline Min. - Max. & & \\
\hline Mean \pm SD & \multicolumn{2}{|c|}{$9.36 \pm 0.98$} \\
\hline Percent score & \multirow{2}{*}{\multicolumn{2}{|c|}{$50.0-75.0$}} \\
\hline Min. - Max. & & \\
\hline Mean \pm SD. & \multicolumn{2}{|c|}{$58.50 \pm 6.15$} \\
\hline
\end{tabular}


Table (4): Frequency and Percent of distribution of practice behaviors among the studied nurses $(n=50)$

\begin{tabular}{|c|c|c|c|c|c|c|c|c|}
\hline & \multicolumn{2}{|c|}{ Always } & \multicolumn{2}{|c|}{ Often } & \multicolumn{2}{|c|}{ Sometimes } & \multicolumn{2}{|c|}{ Rarely } \\
\hline & No. & $\%$ & No. & $\%$ & No. & $\%$ & No. & $\%$ \\
\hline Screen for baseline peripheral neuropathy & 50 & 100.0 & 0 & 0.0 & 0 & 0.0 & 0 & 0.0 \\
\hline Assess fine motor skills & 1 & 2.0 & 49 & 98.0 & 0 & 0.0 & 0 & 0.0 \\
\hline Document CIPN assessment data & 15 & 30.0 & 35 & 70.0 & 0 & 0.0 & 0 & 0.0 \\
\hline Assess deep tendon reflexes & 50 & 100.0 & 0 & 0.0 & 0 & 0.0 & 0 & 0.0 \\
\hline Assess muscle strength & 50 & 100.0 & 0 & 0.0 & 0 & 0.0 & 0 & 0.0 \\
\hline $\begin{array}{l}\text { Assess for other risk factors associated with } \\
\text { peripheral neuropathy }\end{array}$ & 50 & 100.0 & 0 & 0.0 & 0 & 0.0 & 0 & 0.0 \\
\hline Assess motor function skills (e.g., gait) & 50 & 100.0 & 0 & 0.0 & 0 & 0.0 & 0 & 0.0 \\
\hline $\begin{array}{l}\text { Perform CIPN assessment prior to each } \\
\text { neurotoxic chemotherapy infusion }\end{array}$ & 44 & 88.0 & 6 & 12.0 & 0 & 0.0 & 0 & 0.0 \\
\hline $\begin{array}{l}\text { Teach patient strategies for adapting to CIPN } \\
\text { functional impairment }\end{array}$ & 50 & 100.0 & 0 & 0.0 & 0 & 0.0 & 0 & 0.0 \\
\hline $\begin{array}{l}\text { Teach safety precautions used to prevent } \\
\text { injuries associated with CIPN (e.g., falls) }\end{array}$ & 50 & 100.0 & 0 & 0.0 & 0 & 0.0 & 0 & 0.0 \\
\hline $\begin{array}{l}\text { Practice } \\
<75 \text { unsatisfactory } \\
\geq 75 \text { satisfactory }\end{array}$ & & & & & & & & \\
\hline $\begin{array}{l}\text { Total practice } \\
\text { Min. - Max. } \\
\text { Mean } \pm \text { SD. }\end{array}$ & & & & $\begin{array}{r}37.0 \\
38.2\end{array}$ & $\begin{array}{l}40.0 \\
0.67\end{array}$ & & & \\
\hline $\begin{array}{l}\text { Percent practice } \\
\text { Min. - Max. } \\
\text { Mean } \pm \text { SD. }\end{array}$ & & & & $\begin{array}{r}90.0 \\
94.0\end{array}$ & $\begin{array}{l}100.0 \\
2.23\end{array}$ & & & \\
\hline
\end{tabular}


Table (5): Oncology nurses' confidence in performing physical assessment skills regarding chemotherapy induced peripheral neuropathy $(n=50)$

\begin{tabular}{|c|c|c|c|c|c|c|c|c|}
\hline & \multicolumn{2}{|c|}{ Not at all } & \multicolumn{2}{|c|}{ Somewhat } & \multicolumn{2}{|c|}{ Confidence } & \multicolumn{2}{|c|}{$\begin{array}{c}\text { Very } \\
\text { confidence }\end{array}$} \\
\hline & No. & $\%$ & No. & $\%$ & No. & $\%$ & No. & $\%$ \\
\hline Deep tendon reflexes & 21 & 42.0 & 24 & 48.0 & 5 & 10.0 & 0 & 0.0 \\
\hline Tuning fork vibration sensation & 0 & 0.0 & 17 & 34.0 & 33 & 66.0 & 0 & 0.0 \\
\hline Sharp vs. dull sensation & 0 & 0.0 & 21 & 42.0 & 28 & 56.0 & 1 & 2.0 \\
\hline Romberg test & 1 & 2.0 & 0 & 0.0 & 1 & 2.0 & 48 & 96.0 \\
\hline $\begin{array}{l}\text { Manual muscle strength } \\
\text { Testing }\end{array}$ & 13 & 26.0 & 22 & 44.0 & 13 & 26.0 & 2 & 4.0 \\
\hline $\begin{array}{l}\text { Confidence } \\
<50 \text { Low } \\
\geq 50 \text { High } \\
\end{array}$ & \multicolumn{4}{|c|}{17} & & & & \\
\hline $\begin{array}{l}\text { Total confidence } \\
\text { Min. }- \text { Max. } \\
\text { Mean } \pm \text { SD. }\end{array}$ & \multicolumn{8}{|c|}{$\begin{array}{c}7.0-18.0 \\
13.33 \pm 86.67\end{array}$} \\
\hline $\begin{array}{l}\text { Percent confidence } \\
\text { Min. }- \text { Max. } \\
\text { Mean } \pm \text { SD. }\end{array}$ & \multicolumn{8}{|c|}{$\begin{array}{l}13.33-86.67 \\
52.93 \pm 12.66\end{array}$} \\
\hline
\end{tabular}

Table (6): Relation between oncology nurses' knowledge with practice behaviors and confidence $(\mathrm{n}=50)$

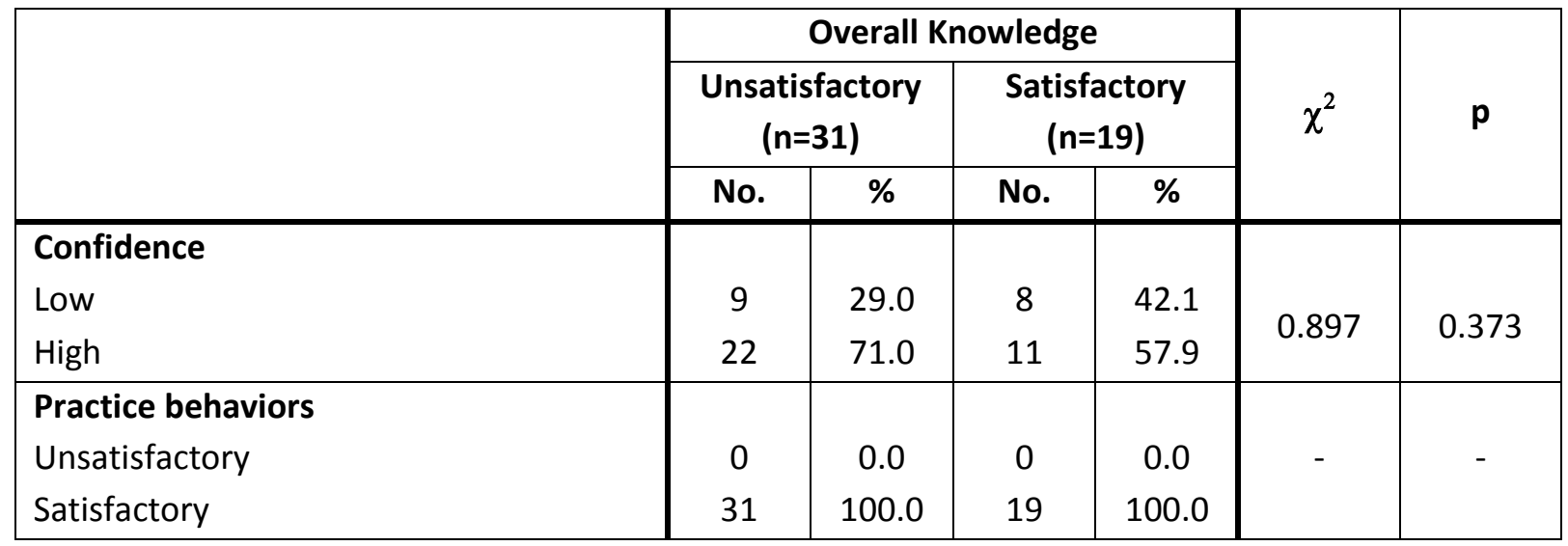

Table (7): Correlation between nurses' Knowledge with practice behaviors and confidence $(\mathrm{n}=50)$

\begin{tabular}{|l|c|c|}
\hline & $\mathbf{r}$ & $\mathbf{P}$ \\
\hline Knowledge vs practice & $0.291^{*}$ & $0.041^{*}$ \\
\hline Knowledge vs confidence & -0.141 & 0.329 \\
\hline Practice vs confidence & $-0.503^{*}$ & $0.001^{*}$ \\
\hline
\end{tabular}

r: Pearson coefficient $\quad *$ : Statistically significant at $\mathrm{p} \leq 0.05$ 


\section{DISCUSSION:}

This study was initiated in recognition of the profound, negative effect CIPN has on the daily living of patients with varied cancer diagnoses and the lack of a standard approach among oncology nurses in addressing the care of patients who receive neurotoxin agents. This study may validate the existence of gaps in oncology nursing knowledge, practice behaviors and confidence pertaining to CIPN. These deficits, unless corrected, negatively influence patient outcomes, physical function, and enjoyment of life in those who are diagnosed with CIPN.

The result of the present study revealed that, less than two thirds of the studied nurses had unsatisfactory total knowledge score regarding chemotherapy induced peripheral neuropathy. This indicates that there is a need for on-going education regarding the nonpharmacologic management, pharmacologic agents, neuropathy terminology, assessment principals, and symptomatology specific to CIPN among new oncology nurses and experienced oncology nurses alike. Education through continuing education programs, oncology nursing specific educational forums, college courses, and pharmaceutical industry initiated educational endeavors are necessary in providing oncology nurses' with the knowledge necessary to care for patients receiving neurotoxic chemotherapeutic agent .

This result was in accordance with (Smith, et al., 2014) who studied nursing knowledge, practice patterns, and learning preferences regarding chemotherapy-induced peripheral neuropathy and found that nurses in the survey lacked knowledge regarding neurotoxicity of specific agents and evidence-based treatments. The result of study finding was disagree with (McAllister, 2010) who studied oncology nurses' knowledge, practice behaviors, and confidence specific to chemotherapy induced peripheral neuropathy and found that the mean chemotherapy-induced peripheral neuropathy knowledge score indicated adequate knowledge.

The result of the present study revealed that, all of the studied nurses had satisfactory practice behaviors total score regarding chemotherapy induced peripheral neuropathy except in area of assessment of fine motor skills ,documentation CIPN assessment data, and CIPN assessment prior to each neurotoxic chemotherapy infusion. This may be related to more than two fifths of nurses were bachelor level of education, more than half of nurses had 5-10 years of experience, more than half of nurses had 5-10 years of experience in oncology, all of nurses received oncology patients' care training courses and the majority of nurses received chemotherapy training courses. This study result was disagree with the study done by (Binner, 2010) who found that the oncology nurses had adequate nursing practice regarding chemotherapy induced peripheral neuropathy and assessment practices did not routinely include neurologic physical assessment.

The result of the present study showed that about two thirds of the studied nurses had high confidence score regarding chemotherapy induced peripheral neuropathy whereas the majority of participants reported greater confidence in performing Romberg test, 
more than half exhibit confidence in assessing tuning fork vibration sensation and sharp vs. dull sensation and less

than half exhibit a lack of confidence in deep tendon reflexes, and manual muscle strength testing. The lack of confidence may indicate that these skills require a higher level of assessment knowledge in perform it and there may be a knowledge deficit in interpreting the findings. It may be also referred to that, the oncology nurses were never educated in performing these skills and neurological assessment skills may be perceived as the responsibility of the physician or nurse practitioner. This study result was in the same line with Visovsky, et al (2012) who reported that, there was lack in confidence and skill for performing the subjective and objective assessments of CIPN in patients pretest.

The result of the study showed that there were positive correlation between nurses' knowledge and practice, negative correlation between knowledge and confidence but it did not reach a significant level, and a statistically significant negative correlation between practice and confidence. Also there were statistically significant relation between knowledge and practice. From the point view of the researcher, this may be due to knowledge is pre-requisite to practice and the finding of the result reflect the need for providing oncology nurses with continued education, and the need to teach oncology nurses the skills necessary to confidently assess for CIPN. Also, this study may validate the existence of gaps in oncology nursing

Knowledge, practice behaviors and confidence pertaining to CIPN.

\section{CONCLUSION:}

The results of the present study concluded that, there were no statistically significant relations between oncology nurses' knowledge with practice behaviors and confidence, there were positive correlation between nurses' knowledge and practice, there were negative correlation between knowledge and confidence but it did not reach a significant level and there were statistically significant negative correlation between practice and confidence.

\section{RECOMMENDATIONS:}

From the foregoing discussion, we can suggested some guidelines for oncology nurses, hospital directors, oncology medicine doctors and further research studies as follows:

- Offer standard guidelines in both labeled wall chart and online access to be easily reachable for oncology nurses

- Encourage nurses and oncology medicine physicians to cooperate together in assess and detect early signs and symptoms of Chemotherapy Induced Peripheral Neuropathy

- Give nurses confidence to apply neurological tests and follow -up regarding assess patients under chemotherapy for peripheral neuropathy 
- Hospital directors should offer an educational practical workshops for oncology nurses regarding neurological tests especially for Chemotherapy Induced Peripheral Neuropathy

- Further research studies on implementing an educational program for oncology nurses regarding preventive measures and functional status of Chemotherapy Induced Peripheral Neuropathy showed a remarkable increase demand.

- Within this context, there is a great demand for strategies and programs that take into consideration all the social, financial, and psychological contexts of this disease.

- Efforts should be carried out to design and implement interventions that suit the oncology field evidence in another geographical area.

- Health education programs should be developed and carried out about additional guidelines that address hazardous drugs or the equipment in which they are manipulated

- Periodic check up for nurse for early detection of occupational hazard to monitor the health status and early case finding.

\section{REFERENCES:}

Argyriou, A; Kyritsis, A.P; s Makatsoris, T; Kalofonos, H.P. ( 2014 ) : Chemotherapy-induced peripheral neuropathy in adults: a comprehensive update of the literature, Open access peer-reviewed scientific and medical journals19 March 2014 Volume 6 Pages 135-147

Binner, M. (2010): Chemotherapy-induced peripheral neuropathy: Assessment of oncology nurses' knowledge and practice. Poster session presented at the. $16^{\text {th }}$ Annual International Conference on Cancer Nursing (ICCN), Atlanta, GA.

Cavaletti ,G.1 ; Frigeni ,B ; Lanzani , F, Mattavelli , L; Susani , E; Alberti , P ; Cortinovis , D ; Bidoli , P . (2009): Chemotherapy-Induced Peripheral Neurotoxicity assessment: a critical revision of the currently available tools. Eur J Cancer. 2010 Feb;46(3):479-94. doi: 10.1016/j.ejca.2009.12.008. Epub 2010 Jan 4.

Elgharib, E.I ; Mohamed, M.A; Elsharkawy, S. J ; Qalawa, sh.A .(2012) : Nurses performance regarding infection control measures in caring for patient with postoperative wound, unpublished master thesis, faculty of nursing, Port said university :p.56

Hoffman, A.J .(2013): Enhancing Self-Efficacy for Optimized Patient Outcomes through the Theory of Symptom Self-Management, Cancer Nurs; 36(1): P 17

Jeffries, P. R., \&Rizzolo, M. A. (2006): Designing and implement models for the innovative use of simulation to teach nursing care of ill adults and children: A national, multi-site, multi-method study. Retrieved from NLN website , p.4

Maloney, K.W . (2012): Nursing Management of Chemotherapy-Induced Peripheral Neuropathy, University of Pennsylvania School of Nursing :p.5 
Martelli-Reid, L. S ; Baker, C.A ; Smith, Y.C ; Ung, W.K ; and members of the Lung Cancer Disease Site Group .(2007): Postoperative Adjuvant Chemotherapy in Completely Resected Non-Small Cell Lung Cancer: Guidance for Nurses , A Quality Initiative of the Program in Evidence-based Care (PEBC), Cancer Care Ontario (CCO) Developed by the Lung Cancer Disease Site Group. P.7

McAllister , D.(2010): Evaluation of Oncology Nurses' Knowledge, Practice Behaviors, and Confidence Specific to Chemotherapy Induced Peripheral Neuropathy, published master thesis in nursing science, College of Nursing, University of South Florida

Meghna, S ; Trivedi, M.D; Dawn ,L ; Hershman, M.D; Katherine ,D ; Crew ,D .(2016): Management of Chemotherapy-Induced Peripheral Neuropathy , American Journal of Hematology / Oncology ,1(1):p.1

Miltenburg, N. C ; Boogerd , W. (2014): Chemotherapy-induced neuropathy: A comprehensive survey. Cancer Treat Rev. 2014 Aug; 40(7):872-82. doi: 10.1016/j.ctrv.2014.04.004. Epub 2014 Apr 18.Oncology nurses' knowledge and practice. Poster session presented at the 16th, Annual International Conference on Cancer Nursing (ICCN), Atlanta, GA.

Occupational Safety and Health administration (OSHA)(2010): Personal protective equipment . Retrived May,20,2010, from http//www.osh.gov.

Park, S ; Goldstein , D ; Krishnan, A ; Lin , C. S ; Friedlander , M ; Cassidy , J ; Kolzenburg , M ; Kiernan , M. (2013): Chemotherapy-induced peripheral neurotoxicity: A critical analysis. Cancer Journal for Clinicians, 63(6), 430.

Krstev S, Peruničić B, Vidakovic A. Work practice and some adverse health effects in nurses handling antineoplastic drugs. Med Lav 2003;94(5):432-439

Schloss, $J$.(2016): A pilot clinical trial assessing the efficacy and safety of supplementation with a $\mathrm{B}$ complex vitamin to reduce the incidence of chemotherapy induced peripheral neuropathy in patients diagnosed with a malignancy, published doctorate thesis, School of Medicine, The University of Queensland :p404

Smith EM, Campbell G, Tofthagen C, Kottschade L, Collins ML, Warton C, Ghosh B, Ronis DL, Mallory GA, Visovsky C. (2014):OncolNurs Forum. Nov 1;41(6):669-79

Smith, E.L., Beck, S.L., \& Cohen, J. (2008) : The total neuropathy score: A tool for measuring chemotherapy-induced peripheral neuropathy. Oncology Nursing Forum, 35(1), 96-102.

Visovsky C, Haas M , Faiman B , Kurtin S, Shaftic AM, Lyden E, and Rice J (2012): Nurse Self-Evaluation of Assessmentof Chemotherapy-Induced PeripheralNeuropathy in Patients With Cancer.Journal of the Advanced Practitioner in Oncology [2012, 3(5):319-325]

Wickham $R$.(2007): Chemotherapy-induced peripheral neuropathy: a review and implications for oncology nursing practice. Clin J OncolNurs. 2007 Jun;11(3):361-76. 
العلاقة بين السلوك المهاري لممرضين الاورام ومعلوماتهم وثقتهم تجاه ضمور الاطراف العصبية المصاحب للعلاج الكيماوى

شيرين احمد قلاوة ـ دينا التابعي صبح صبيح ـ فاطمة الامام حافظ

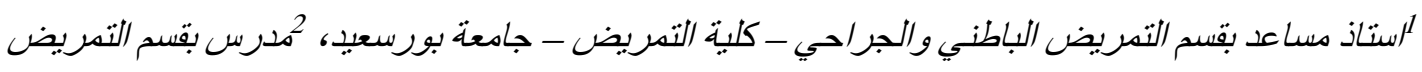
الباطني والجراحي - كلية التهريض - جامعة بورسعبي، 3درس بقسم تصريض صحة الاسرة والمجتمع-كلية التمريض- جامعة بورسعبي

\section{الخلاصة}

ضمور الاطر اف العصبية المصاحب للعلاج الكيماوى هو أحد الآثار الجانبية المدمرة الجسيمة الناجمة عن اعطاء العلاج الكيميائي العصبي. الهُف: تهدف هذه الدر اسة إلى العلاقة تحديد بين السلوك المهاري لممرضين الاورام ومعلو ماتهم وثقتهم تجاه ضمور الاطر اف العصبية المصاحب للعلاج الكيماوى. طرق البحث المستخدمة: نم استخدام تصميم البحث الوصفي الاستكثافي لتحقيق هدف الدراسة. العينة: وقد تألفت عينة الدر اسة من كل الممرضين

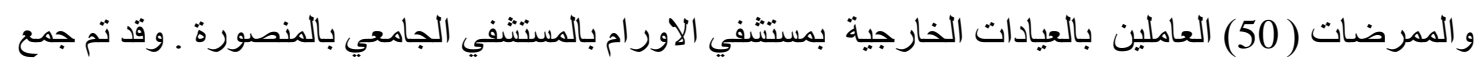
البيانات من سبتمبر الى ديسمبر في عام 2016. وأدوات جمع البيانات: استمارة واحدة تثتمل علي اربع اجز اء منها

أستمارة بيانات الخصائص النخصية و الوظيفية،استمارة لتقييم السلوك المهاري، استمارة لتقييم المعرفة واستمارة لتقييم الثقة الذاتية ـ النتائج: أظهرت النتائج أن 62.0٪ من الممرضين لديهم مستوي غير مرضي من المعلومات ، كل

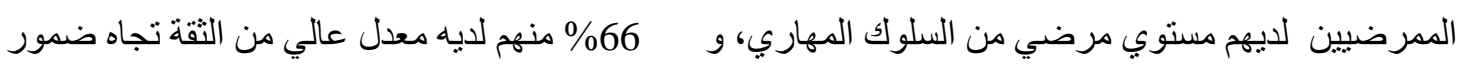
الاطر اف العصبية المصاحب للعلاج الكيماوى. الأستنتاجات: وفقا للمشاركين، لا يوجد علاقة ذات دلالة إحصائية

بين بين السلوك المهاري لممرضين الاور ام ومعلوماتهم وثتتهم تجاه ضمور الاطر اف العصبية المصاحب للعلاج الكيماوى. وجود نقص في المعرفة المتعلقة بضمور الاطر اف العصبية المصاحب للعلاج الكيماوى مع نقص الي الي التدريب و الكفاءة و الثقة في التقييم البدني العصبي. التوصيات: لرفع مستوى معرفـة وممارسـات الممرضين فيما

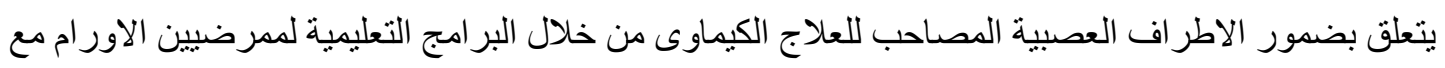
اعطاء الثقة الكافية للممرضيين اثناء الاختبار ات العصبية والمتابعة. 